\title{
NFAT5 Gene
}

National Cancer Institute

\section{Source}

National Cancer Institute. NFAT5 Gene. NCI Thesaurus. Code C93131.

This gene is involved in gene transcription and cellular stress responses. 